\title{
EFFECT OF WATER DEFICIT ON THE GROWTH, YIELD AND ESSENTIAL OIL CONTENT OF LEMONGRASS IN VIVO.
}

\author{
K. E. Mazrou(1), I. A. Ibrahim(1), S.A. Alabsawy(2), K.G.Gharib(1) \\ (1) Dep. of Plant Biotechnology, Genetic Engineering and Biotechnology Research \\ Institute, University of Sadat City, Egypt. \\ (2) Dep. of Bioinformatics, Genetic Engineering and Biotechnology Research institute, \\ University of Sadat City, Egypt.
}

Received: Jul. 25, 2018

Accepted: Aug. 26, 2018

\begin{abstract}
Two field experiments were carried out on Cymbopogon citratus, during two years of 2015 and 2016 at Al Khtatbah, Sadat Center, Minufiya Governorate, Egypt. The aim of this research work was to study the effect of drip irrigation regimes $(24,12,8$ and 4 liters/plant/week) on yield and essential oil content of lemongrass. All growth and yield characters were significantly affected by the deficit of irrigation water. The plant height, number of tillers, fresh and dry weights / plant, fresh and dry yield per hectare) as well as nutrient content in the dry herb, essential oil percentage and oil yield of lemongrass decreased as affected by water deficit in all cuts of the two experimental seasons. However, the highest irrigation regime (24 liters/plant/week) provided the best results in this respect. On the other hand, the best quality of the essential oil (concentration of citral) was obtained at the lower regime (8 liters /plant/week).
\end{abstract}

Key words: Water stress, Cymbopogon citratus, essential oil, secondary product, NPK\%.

\section{INTRODUCTION}

Cymbopogon citratus, Family:

Poaceae (Gramineae) commonly, known as lemongrass is considered as one of the most important plants that has an attractive economic value due to its medicinal and biochemical properties (Abdou et al. 2014 and Hamed et al. 2017), this importance due to its essential oil content, which contains citral as a main component (Rehman et al. 2016).

Furthermore, the essential oil has a great value for pharmaceuticalindustries, it is used as antibacterial, antifungal (Bayala et al., 2014), antiprotozoal, anticancer, anti-inflammatory, antiseptic (Bayala et al., 2018; Maruoka et al., 2018), decreased total cholesterol and lowdensity lipoprotein and act as strong antioxidant (Somparn et al., 2018), perfumes and cosmetic industries (Chen 2018).
Besides, notable for its lemon flavor and fragrance, it is widely used in cooking as a major source of lemon flavoring in the food additives (Ferreira et al., 2017), eco-friendly pesticides (Mao et al., 2018), Fresh herb is also containing small amounts of vitamins such as vitamin-A and $C$; Bionones are used in the synthesis of Vitamin-A (Venugopal 2010). Also have rich source of minerals like potassium, zinc, calcium, iron, manganese, copper, and magnesium (Abdel-kader et al., 2014). Biomass crop may have applications for biofuel production, and as a non-edible plant oil source for biodiesel production (Binu et al., 2013 \& Alagumalai 2015).

Water supply shortages becomes a critical constraint on water future use in Egypt, It is well known that water resources in Egypt are limited to the share of Egypt in the flow of the Nile River by 55.5 million $\mathrm{m}^{3}$, the deep 
groundwater in the deserts (mostly nonrenewable) and a small amount of rainfall in the northern coastal area and Sinai (Eissa et al., 2018), Ethiopia Dam shapes a great future problem for Egypt water availability from Nile River (Shaalan et al. 2018), Increases in dam and irrigation development in upstream parts of the basin is poised to conflict with agricultural expansion and population growth in Egypt (Molle et al., 2018).

Whereas, the human population is approximately 95 million with an increasing rate reaches to $2.4 \%$ per year, (Central Agency for Public Mobilization a nd Statistics, 2017).

Water stress in plants may lead to physiological disorders, such asa reduction in photosynthesis and transpiration, translocation, ion uptake, carbohydrates, nutrient metabolism and hormones as argued by (Moradi 2014). So it can be defined as the absence of adequate moisture necessary for normal plant growth and to complete the life cycle (Zhu, 2002).

Water stress reduce growth and yield due to reduction in photosynthesis and plant biomass (Bahreininejad et al., 2013) up to photosynthesis was limited by low CO2 availability due to reduced stomatal and mesophyll conductance (Elansary et al., 2016), Whereas drought stress is associated with stomatal closure and thereby with decreased $\mathrm{CO} 2$ fixation (ELAttar \& Ashour, 2016).

This study aimed to investigate the possible effect of water stress on the vegetative growth, essential oil content, and chemical content of lemongrass.

\section{MATERIALS AND METHODS}

This investigation was carried out at a private Farm located $\left(30^{\circ} 21^{\circ} 544799 \mathrm{~N}, 30^{\circ}\right.$ 49 15.3899E) in Al khatatabah, Sadat City, Minufiya Governorate, Egypt during two successive seasons of 2015 and 2016 on
Cymbopogon citratus plants for study the effect of water regime under drip irrigation on vegetative growth, essential oil content, quality and chemical composition of on Cymbopogon citratus plants, the all data were taken at the laboratory of medicinal and aromatic plants, Plant Biotechnology Department Genetic Engineering and Biotechnology Research Institute (GEBRI), Sadat City University, Egypt.

The lemongrass transplants were transplanted in the prepared nursery on $15^{\text {th }}$ November in both seasons in experimental farm of (GEBRI). The soil was prepared and divided into plots of 1.5 $\times 2.5$. Each plot contained two rows and eight plants at a distance of $50 \mathrm{~cm}$ apart. The homogenous transplants were cultivated in the experimental farm on the first of March during the two experimental seasons.

1- Treatments: the water regimetreatments were 24, 12, 8 and 4 liters/plant/week in both seasons of the experiment, starting from the first of May to the first of November.

2- Statistical analysis: all plants received the required agricultural practices. The plants were cut two times, the first cut was on $15^{\text {th }}$ July and the second was on $15^{\text {th }}$ October during the two seasons. Plants were cut at height of $15 \mathrm{~cm}$ above the soil surface. The following experiments were planned in a complete randomized design with three replicates, the data analyzed by analysis of variance (ANOVA), using COSTAT Statistical software (computer program).

3-The experimental soil and fertilizers properties:

a. the experimental soil: was sandy in texture its chemical properties estimated according to (Webster\& Lark, 2018) and presented in Table (1). 
Effect of water deficit on the growth, yield and essential oil content of .......

Table (1): The mechanical and chemical analysis of the experimental soil were as following:-

First: mechanical analysis

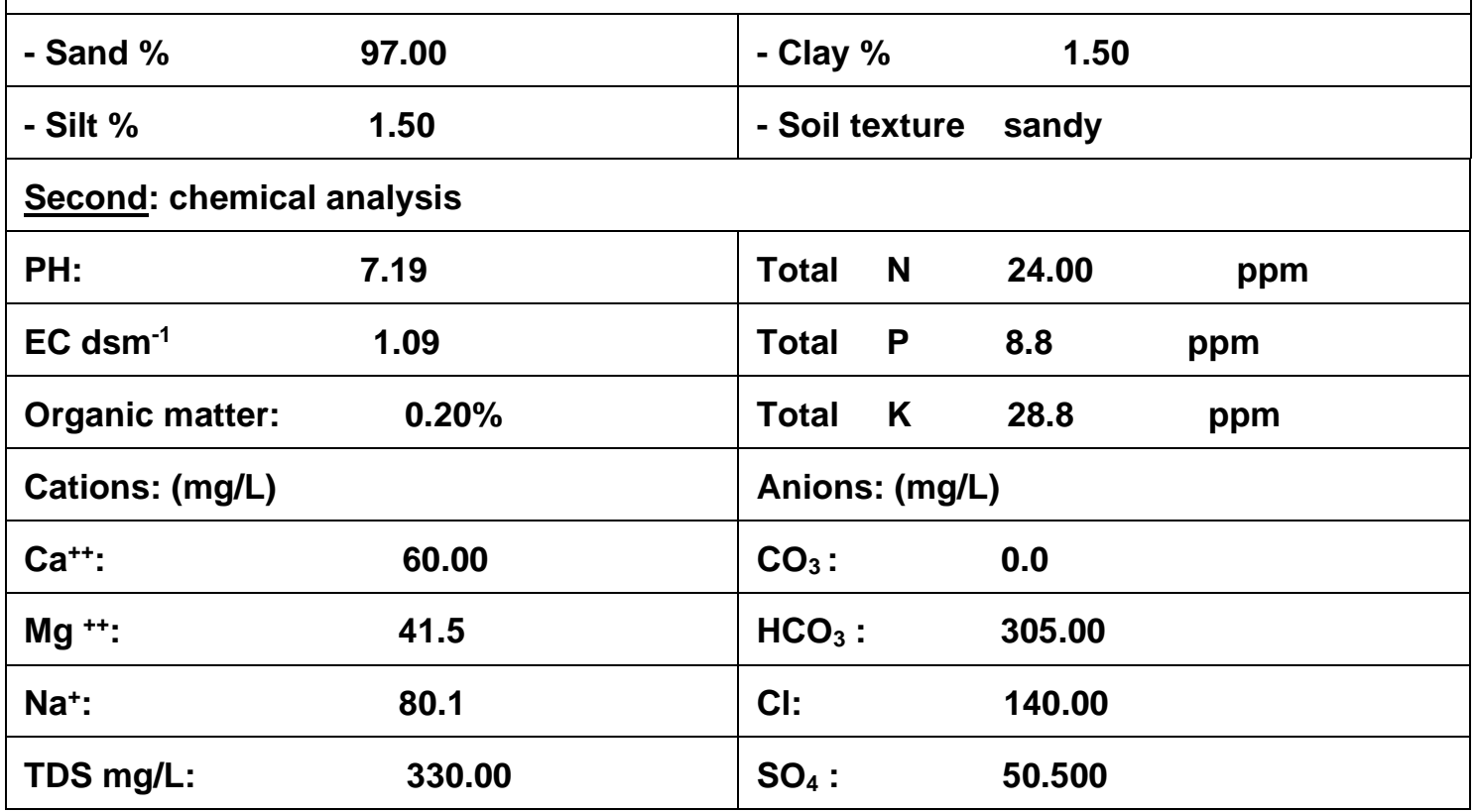

Where, TDS: Total Dissolved Solids.

E.C: Electrical Conductivity.

b. Compost: the compost used at 30 $\mathrm{m}^{3} /$ hectare in organic fertilizers, the physical and chemical characteristics of the Compost produced by Quesna Company, presented Table (2).

c. Chemical fertilizers: The recommended dose of mineral fertilization according to Ministry of Agriculture was used as follows:

- Ammonium sulphate $(20.5 \% \mathrm{~N})$ at 700 $\mathrm{kg} /$ hectare.

- Calcium super phosphate (15.5\% $\left.\mathrm{P}_{2} \mathrm{O}_{5}\right)$ was added at $240 \mathrm{~kg} / \mathrm{hectare}$, when the soil prepared.

- Potassium sulphate $\left(48 \% \mathrm{~K}_{2} \mathrm{O}\right)$ was added at $120 \mathrm{~kg} / \mathrm{hectare}$ with nitrogen fertilizer at 2 equal doses. The first addition was done after 45 days of transplanting and the second was after the first cut.

4-Chemical analysis:-

Nitrogen, phosphorus, potassium content in the dried herb of lemongrass were determined by Kiel Dahl method (Cottenie et al. 1982).

\section{5- Essential oil content:}

a- The oil percentage:

The essential oil obtained performed as described by (Venzon et al., 2018), collected plant material (whole plants), the leaves were transected in lengths of approximately $2 \mathrm{~cm}$, then was washed thoroughly with distilled clean water and crushed into smaller pieces. The plant material was transferred to storage in a glass beaker. Thereafter, boiled in distilled water (100 $\mathrm{g}$ of plant material in $1000 \mathrm{~mL}$ of water) for $2 \mathrm{~h}$ and the hydro distillation extraction method was performed using the Clevenger apparatus and aliquots of the essential oil were placed in micro tubes. The extract was stored at $-80^{\circ} \mathrm{C}$ until use. The essential oil was obtained by hydro-distillation expressed as $\mathrm{ml} 100 \mathrm{~g}^{-1}$ fresh herb. 
K. E. Mazrou, et al.,

Table (2): Physical and chemical properties of used compost:

\begin{tabular}{|c|c|}
\hline Properties & Statement \\
\hline Volume of $1 \mathrm{~kg}\left(\mathrm{~m}^{3}\right)$ & 1.2 \\
\hline Moisture content (\%) & $21.1 \%$ \\
\hline Organic Matter (\%) & $35.8 \%$ \\
\hline Organic Carbon (\%) & $12.6 \%$ \\
\hline Total N (\%) & $1.4 \%$ \\
\hline C:N ratio & $9: 1$ \\
\hline Total P (\%) & $0.88 \%$ \\
\hline Total K (\%) & $1.11 \%$ \\
\hline Total Ca (\%) & $4.6 \%$ \\
\hline Total Mg (\%) & $0.2 \%$ \\
\hline Fe (\%) & $0.55 \%$ \\
\hline Mn (ppm) & 100 \\
\hline Zn (ppm) & 100 \\
\hline EC & 4.88 \\
\hline PH & 7.9 \\
\hline
\end{tabular}

The volatile oil percentage was determined in the fresh herb obtained from each replicate in all cuts during the two experimental seasons, by using the water described by (British Pharmacopeia 1963).

b. Gas Chromatography and Mass Spectrometry (GC-MS) analysis of essential oil:

The essential oil obtained from the second cut in the second season was analyzed using GC-MS apparatus at GC/MS LAB of National Research Center (NRC), Giza, Egypt.

\section{RESULTS AND DISCUSSION}

\section{Growth parameters:}

\subsection{Plant height:}

The recorded Data in Table (3) clearly indicate that all studied growth and yield characters were significantly affected by the irrigation regime. The Plant height was significantly reduced under water stress conditions in both seasons and this effect was more pronounced with increasing the severity of water stress in two experimental seasons by decreasing of water amount from 24 liters/plant/week to 4liters/plant/week, plant height $(\mathrm{cm})$ showed significant reduction.

The irrigated plants 24liters /plant/ week significantly resulted in the tallest plants in each cutting in two growing seasons in comparison to the irrigation 12, 8 and 4 liters/plant/week. Meanwhile the treatment of watering 4 liters/ plant/week produced the shortest plants in both seasons. the plant height in the first cutting in the second season was (116.8), (98.5), (79.4) and (56.4) whereas, it was (158.6), (148.8), (129.7) and (88.3) $\mathrm{cm}$ in the second cutting experimental season for the treatments irrigation 24, 12,8 and 4 liters/plant/week respectively. 
Effect of water deficit on the growth, yield and essential oil content of .......

Table (3): Effect of water regime on plant height and the number of tillers per plant.

\begin{tabular}{|c|c|c|c|c|c|c|c|c|}
\hline \multirow{2}{*}{$\begin{array}{c}\text { Treatment of } \\
\text { Water regime } \\
\text { liters/plant/week }\end{array}$} & \multicolumn{4}{|c|}{ Plant height in cm } & \multicolumn{3}{c|}{ Number of tillers per plant } \\
\cline { 2 - 9 } & \multicolumn{2}{|c|}{$1^{\text {st }}$ season } & \multicolumn{2}{c|}{$2^{\text {nd }}$ season } & \multicolumn{2}{c|}{$1^{\text {st }}$ season } & \multicolumn{2}{c|}{$2^{\text {nd }}$ season } \\
\cline { 2 - 9 } & $1^{\text {st }}$ cut & $2^{\text {nd }}$ cut & $1^{\text {st }}$ cut & $2^{\text {nd }}$ cut & $1^{\text {st }}$ cut & $2^{\text {nd }}$ cut & $1^{\text {st }}$ cut & $2^{\text {nd }}$ cut \\
\hline 24 & 111.8 & 151.2 & 116.8 & 158.6 & 23.4 & 46.1 & 23.8 & 56.1 \\
\hline 12 & 101.5 & 133.8 & 98.5 & 148.8 & 20.8 & 40.7 & 20.9 & 46.7 \\
\hline 8 & 80.9 & 125.6 & 79.4 & 129.7 & 14.6 & 35.7 & 14.3 & 39.3 \\
\hline 4 & 57.7 & 114.7 & 56.4 & 88.3 & 11 & 27.5 & 11.1 & 32.4 \\
\hline LSD (5\%) & 0.22 & 1.61 & 2.23 & 1.81 & 0.21 & 0.6 & 0.5 & 0.99 \\
\hline
\end{tabular}

These results could explained Such reduction in plant height in response to drought may be due to blocking up of xylem and phloem vessels thus slowness any translocation through (Lovisolo and Schuber 1998) in addition (Ben-zioni et al., 1967) reported that the incorporation of amino acids into protein is inhibited by longer water stress.

Similar results were obtained by (Chakrborty et al., 2010), (Abdel-kader et al., 2014) and (Singh et al., 2016) on lemongrass. Also (Khalil et al., 2013), (Hendawy et al., 2013) and (El-mekawy et al., 2013) reported that reduced water uptake results in decrease in tissue water content.

Therefor under drought stress conditions, cell elongation in plants is inhibited by reduced turgor pressure (EIMekawy et al., 2013). Likewise drought stress also trims down the photoassimilation metabolites required for cell division as consequence impaired mitosis (Farooq et al., 2009), cell elongation and expansion result in reduced plant height and growth (Eiasu et al., 2009) on Pelargonium capitatumplant, (Gerami et al., 2016) on Origanum vulgare $L$ found that water stress negatively affected plant growth.
1.2 Number of tillers/plant:

The data in Table (4) clearly indicate that, the mean number of tillers/plant was markedly increased as a result of increasing of water supply in the two cutting of each experimental season. The treatment of irrigation 24 L/P/W significantly gave more tillers per plant than those of watering 12,8 and 4 L/P/Win both seasons. The lowest values in this concern were produced by watering lemongrass plants 4 L/P/W. For example, the mean number of tillers/ plant in the second cutting of the first season were (46.1), (40.7), (35.7) and (27.5) for treatments of irrigation 24, 12, 8 and 4 L/P/W, respectively.

These results reflect the importance role of the adequate water supply for lemongrass plants in enhancing tillering. This may be due to that drought reduced cycling dependent Kinase (Taiz \& Zeiger 2006) activity results in slower cell division as well as inhibition of growth (Schuppler et al., 1998; Farooq et al., 2009). This supported by the results of (Rahmani et al., 2011) on Calendula officinalis and (El-Mekawy, 2013) on Achillea santouolina.

Similar results were obtained by (Singh et al., 2016) and (Abdel-kader et al., 2014) on lemongrass. 
Table (4): Effect of water regime on the fresh and dry weight of herb.

\begin{tabular}{|c|c|c|c|c|c|c|c|c|c|c|c|c|}
\hline \multirow{3}{*}{$\begin{array}{c}\text { Treatment of } \\
\text { Water regime } \\
\text { liters/plant } \\
\text { Iweek }\end{array}$} & \multicolumn{4}{|c|}{$\begin{array}{l}\text { Herb fresh weight } \\
\text { (g / plant) }\end{array}$} & \multicolumn{4}{|c|}{ Herb dry weight (g/plant) } & \multicolumn{4}{|c|}{$\begin{array}{l}\text { Herb fresh yield (ton } \\
\text { /hectare) }\end{array}$} \\
\hline & \multicolumn{2}{|c|}{$1^{\text {st }}$ season } & \multicolumn{2}{|c|}{$2^{\text {nd }}$ season } & \multicolumn{2}{|c|}{$1^{\text {st }}$ season } & \multicolumn{2}{|c|}{$2^{\text {nd }}$ season } & \multicolumn{2}{|c|}{$1^{\text {st }}$ season } & \multicolumn{2}{|c|}{$2^{\text {nd }}$ season } \\
\hline & $\begin{array}{l}1^{\text {st }} \\
\text { cut }\end{array}$ & $\begin{array}{l}2^{\text {nd }} \\
\text { cut }\end{array}$ & $\begin{array}{l}1^{\text {st }} \\
\text { cut }\end{array}$ & $\begin{array}{l}2^{\text {nd }} \\
\text { cut }\end{array}$ & $\begin{array}{l}1^{\text {st }} \\
\text { cut }\end{array}$ & $\begin{array}{l}2^{\text {nd }} \\
\text { cut }\end{array}$ & $\begin{array}{l}1^{\text {st }} \\
\text { cut }\end{array}$ & $\begin{array}{l}2^{\text {nd }} \\
\text { cut }\end{array}$ & $\begin{array}{l}1^{\text {st }} \\
\text { cut }\end{array}$ & $\begin{array}{l}2^{\text {nd }} \\
\text { cut }\end{array}$ & $\begin{array}{l}1^{\text {st }} \\
\text { cut }\end{array}$ & $\begin{array}{l}2^{\text {nd }} \\
\text { cut }\end{array}$ \\
\hline 24 & 652.3 & 1557 & 705.5 & 1440 & 163.1 & 429 & 178.4 & 360 & 26.09 & 62.27 & 28.22 & 57.60 \\
\hline 12 & 443.2 & 1381 & 450.8 & 1016 & 110.8 & 352.9 & 112.7 & 258.1 & 17.73 & 55.24 & 18.03 & 40.62 \\
\hline 8 & 201.9 & 1136 & 202.8 & 841.1 & 50.49 & 288.9 & 51.54 & 206.8 & 8.08 & 45.44 & 8.11 & 33.64 \\
\hline 4 & 167.2 & 829.9 & 169.5 & 724.4 & 41.83 & 234.7 & 42.41 & 182.1 & 6.69 & 33.20 & 6.78 & 0.00 \\
\hline LSD (5\%) & 5.69 & 11.11 & 14.55 & 17.16 & 1.43 & 21.43 & 5.44 & 4.15 & 0.23 & 0.44 & 0.58 & 0.69 \\
\hline
\end{tabular}

1.3 The fresh weight of herb:

It is evident form the data in Table (4) that, increasing amount of water revealed significant increases in total fresh weight of herb/plant in both seasons. Where, the highest means were recorded with plants received the highest water quantity.

The superiority of the plants that received the highest rate of irrigation quantities in producing the heaviest total plant fresh weight and reached its maximum values in the case of watering 24 L/P/W in the two cutting through two experimental season. Meanwhile, the irrigated plants 12 and 8 L/P/W respectively gave significantly lower fresh weight compared to the watered at 24 L/P/W in both seasons.

On the other hand, the irrigated plants 4 L/P/W significantly resulted in the lowest fresh weight of herb/plant compared to the other treatments. For example the mean fresh weight of herb/plant in the second cutting during the second season were (1440), (1015.56), (841.11) and (724.44) gm/plant for the treatment of watering $24,12,8$ and 4 L/P/W, respectively.

The increment in the obtained fresh weight of herb/plant as a result of reducing water regime could be attributed to the increment in both plant height and number of tillers/plant (Table 4) The pronounced effect of increased irrigation on plant height, number of branches may be attributed to the availability of sufficient moisture around the root concentrated and thus a greater proliferation of root biomass resulting in the higher absorption of nutrients (Tatrai et al., 2016) and water leading to production of higher vegetative biomass (Singh et al., 2016), It was found that increasing levels of water stress reduce growth and yield due to reduction in photosynthesis and plant biomass (Bahreininejad et al., 2013). Under increasing water stress levels photosynthesis was limited by low $\mathrm{CO} 2$ availability due to reduced stomatal and mesophyll conductance (Elansary et al., 2016).

Drought stress is associated with stomatal closure and thereby with decreased $\mathrm{CO} 2$ fixation (EL-Attar \& Ashour, 2016).

Similar results were obtained by (Singh et al. 2016) on Cymbopogon flexuosos S.), (Abdel-kader et al., 2014) on lemongrass and (El-Mekawy, 2013) on Achillea santolina, who reported that the fresh weight of herb/plant were markedly increased as a result of increasing water regime. 
1.4 The dry weight of herb:

The reported data in Table (4) indicate that, the dry weight of herb increased with increase of amount of water in two growing seasons. The highest irrigation treatment 24 L/P/W significantly gave heavier dry weight of herb during the two growing seasons. Whereas, the irrigated plants with 8 L/P/W significantly resulted in higher dry weight of herb per plant and per Fadden than those obtained by the treatment of irrigation 4 L/P/W which gave the lowest values in this respect in the two experimental seasons.

\section{The essential oil content:}

2.1 Essential oil percentage in the fresh herb:

The reported data in Table (5) clearly illustrate that the essential oil concentration in the fresh herb of Cymbopogon citratus plants relatively showed a slight increment with reducing applied water quantities in each cutting during the two experimental seasons. The highest value of essential oil percentage was found in the fresh herb of the irrigation plants at 8 L/P/W.

Meanwhile the treatment of 24 L/P/W resulted in lower oil percentage than of irrigation at 4 L/P/W. Otherwise, obtained herb from the treatment of 24 L/P/W had the lowest values in this respect. For example, the essential oil percentage in the fresh herb of second cutting during the season of 2016 were $(0.33 \%),(0.37 \%)$, $(0.42 \%)$ and $(0.40 \%)$ for treatment of irrigation at 24, 12, 8, and 4 liters/ plant/ week respectively.

These results reflect that, the essential oil concentration was in inverse ratio with the herb yield, and could be explained through the dilution effect in oil concentration as result of increasing in the produced herb yield with reducing amount of water as shown in Table (4).

Drought stress increases the secondary products percentage of more medicinal and aromatic plants(Koyro\& Huchzermeyer, 2018), because in case of stress, more metabolites are produce in the plants and substances prevent from oxidization in the cells (Van Oosten et al., 2017), but secondary products content reduce under drought stress, because the interaction between the amount of the secondary products percentage (Nakamura et al., 2003) and mass production is consider important as two components of the secondary products content (Yadav et al., 2014) and by exerting stress, increases the secondary products percentage, but mass production decreases by the drought stress which led to a higher density of the oil glands due to the reduction in leaf area results in an elevated amount of oil accumulation (Nakamura et al., 2003), therefore secondary products content reduces (Hendawy et al., 2013; Hani et al., 2015). On the other side Water deficit stress induces a decrease in glandular trichome density and size as well. trichomes and pathway gene expression in plants grown under (mild and moderate) water stress conditions (Yadav et al., 2014).

Such result could be supported by the finding of (Abdel-kader et al. 2014) who mentioned that essential oils are the product of the respiratory catabolic processes, which increase under the dry conditions of the growing site.

\subsection{The essential oil yield per plant (cc):}

It is evident from the data in Table (4) that the essential oil yield /plant as well as per Fadden significantly increased with increasing of water quantity in each cutting through the two growing seasons. The treatment irrigation of 24 L/P/W gave significantly higher oil yield than those of watering at 12,8 and 4 L/P/W in the two experimental seasons. 
Table (5): Effect of water regime on the essential oil percentage\%.

\begin{tabular}{|c|c|c|c|c|c|c|c|c|c|c|c|c|}
\hline \multirow{3}{*}{$\begin{array}{c}\text { Treatment of } \\
\text { Water regime } \\
\text { liters/plant/week }\end{array}$} & \multicolumn{4}{|c|}{ Essential oils percentage } & \multicolumn{4}{|c|}{ Oil yield (cc/ plant) } & \multicolumn{4}{|c|}{ Oil yield (L/ hectare) } \\
\hline & \multicolumn{2}{|c|}{$1^{\text {st }}$ season } & \multicolumn{2}{|c|}{$2^{\text {nd }}$ season } & \multicolumn{2}{|c|}{$1^{\text {st }}$ season } & \multicolumn{2}{|c|}{$2^{\text {nd }}$ season } & \multicolumn{2}{|c|}{$1^{\text {st }}$ season } & \multicolumn{2}{|c|}{$2^{\text {nd }}$ season } \\
\hline & $\begin{array}{l}1^{\text {st }} \\
\text { cut }\end{array}$ & $\begin{array}{l}2^{\text {nd }} \\
\text { cut }\end{array}$ & $\begin{array}{l}1^{\text {st }} \\
\text { cut }\end{array}$ & $\begin{array}{l}2^{\text {nd }} \\
\text { cut }\end{array}$ & $\begin{array}{l}1^{\text {st }} \\
\text { cut }\end{array}$ & $\begin{array}{l}2^{\text {nd }} \\
\text { cut }\end{array}$ & $\begin{array}{l}1^{\text {st }} \\
\text { cut }\end{array}$ & $\begin{array}{l}2^{\text {nd }} \\
\text { cut }\end{array}$ & $\begin{array}{l}1^{\text {st }} \\
\text { cut }\end{array}$ & $\begin{array}{l}2^{\text {nd }} \\
\text { cut }\end{array}$ & $\begin{array}{l}1^{\text {st }} \\
\text { cut }\end{array}$ & $\begin{array}{l}2^{\text {nd }} \\
\text { cut }\end{array}$ \\
\hline 24 & 0.357 & 0.334 & 0.341 & 0.33 & 2.32 & 5.26 & 2.42 & 4.73 & 92.80 & 210.40 & 96.80 & 189.20 \\
\hline 12 & 0.403 & 0.38 & 0.386 & 0.37 & 1.79 & 5.21 & 1.75 & 3.82 & 71.60 & 208.40 & 70.00 & 152.80 \\
\hline 8 & 0.485 & 0.423 & 0.427 & 0.422 & 0.98 & 4.81 & 0.87 & 3.55 & 39.20 & 192.40 & 34.80 & 142.00 \\
\hline 4 & 0.451 & 0.413 & 0.413 & 0.408 & 0.76 & 3.44 & 0.71 & 2.99 & 30.40 & 137.60 & 28.40 & 119.60 \\
\hline LSD (5\%) & 0.015 & 0.0012 & 0.009 & 0.006 & 0.06 & 0.05 & 0.06 & 0.06 & 2.40 & 2.00 & 2.40 & 2.40 \\
\hline
\end{tabular}

Meanwhile, the irrigated plants every 4 liters/plant/week significantly produced the lowest oil yield compared with the other irrigation levels. The total oil yield/hectare/ season was (210.4), (208.4), (192.4) and (137.6) L/hectare for the treatments of irrigation at 24, 12, 8 and 4 L/P/W respectively in the first experimental season.

The increment in the obtained oil yield as a result of reducing water quantities could be attributed to the increment in the corresponding fresh herb yield (Table 4). Water deficit in plants may lead to physiological disorders, such as a reduction in photosynthesis and transpiration that may cause changes in the yield and composition of essential oil in aromatic plants has been suggested by (Eiasu et al. 2009). Beside this alterations in oil accumulation are considered to be mainly due to its effect on plant growth and differentiation. Reduction of leaf area under stress enhances the density of the oil glands and oil accumulation, the highest essential oil yield per unit area was produced under moderate water stress (Golezani et al., 2008).

\subsection{Alterations in oil composition with water regime:}

The selected samples of lemongrass essential oil were obtained by hydro distillation of the fresh herb from the $2^{\text {nd }}$ cutting at the end of the second season. Essential oil constituents were identified based on their retention time and by coinjection with authentic compounds and mass- spectrophotometry to determine the relative peak area for individual constituents for each volatile oil sample. In all cases number of peaks was identical and there were some of changes in the concentration of individual essential oil constituent.

Differences in the concentration of 7 identified constituent of lemongrass oil were observed in Table (6). There were 4 major hydrocarbons constituent in the volatile oil: the volatile oil: myrcene, allo $\&$ cis ocimene, limonine and $\alpha \& \beta$ pinen. The citral content in lemongrass oil higher than $75 \%$ is considered as high quality product (Rehman et al. 2016). It could be observed that, total hydrocarbon constituents decreased with decreasing of water regime. Maximum limonene content (4.02\%) was obtained with the treatment of irrigated at 12 L/P/W. Meanwhile limonene content (2.02\%, $2.8 \%$ and $3.52 \%)$ was obtained from plants irrigated at 24, 8 and 4 L/P/W respectively. 
Effect of water deficit on the growth, yield and essential oil content of .......

Table (6): Effect of water regime on the percentage of essential oil constituents in the dried leaves of plant.

\begin{tabular}{|c|c|c|c|c|}
\hline Constituents \% & $\begin{array}{c}24 \\
\text { liters/plant/ } \\
\text { week }\end{array}$ & $\begin{array}{c}12 \text { liters/plant/ } \\
\text { week }\end{array}$ & $\begin{array}{c}8 \text { liters/plant/ } \\
\text { week }\end{array}$ & $\begin{array}{c}4 \text { liters/plant/ } \\
\text { week }\end{array}$ \\
\hline 2 Pentanol & 0.27 & 0.27 & 0.27 & 0.48 \\
\hline Myrcene & 7.59 & 7.28 & 6.75 & 3.66 \\
\hline p-mentha $1,5,8$ triene & 0.86 & 0.8 & 0.76 & 1.91 \\
\hline Allo,cis ocimene & 0.96 & 0.53 & 0.44 & 1.5 \\
\hline Limonene & 2.02 & 4.02 & 2.8 & 3.52 \\
\hline Fenchone & 0.24 & 0.22 & 0.18 & 0 \\
\hline Myrtanal & 0.32 & 0.15 & 0 & 0 \\
\hline Caran 4ON,3hydroxy & 0.21 & 0.24 & 0 & 0 \\
\hline$\& \beta$ Pinene & 0.66 & 0.32 & 0.3 & 0.71 \\
\hline Linalool & 1.75 & 1.23 & 1.22 & 2.98 \\
\hline Trans chrysanthmal & 0.39 & 0.38 & 0.35 & 0.25 \\
\hline Verbenol & 1.06 & 0.9 & 0.88 & 2.64 \\
\hline E,z Cirtal & 76.89 & 78 & 81.2 & 76.85 \\
\hline Nerol & 0.40 & 0.36 & 0.33 & 0.73 \\
\hline Geraniol & 3.16 & 4.85 & 4.21 & 3.55 \\
\hline Trans caryophyllen & 0.32 & 0.34 & 0.31 & 0.73 \\
\hline Unknown compounds & 2.91 & 0.12 & 0 & 0 \\
\hline
\end{tabular}

Otherwise, citral as major aldehyde constituent in the oil was increased by decreasing water regime. For example, the highest citral percentage was (81.2\%) in samples from plants irrigated at 8 L/P/W. These results are agreement with (Abdel-kader et al., 2014), who assured the above mentioned results and attributed it to the higher density of glandular hairs and greater content of major constituents with water deficit Moreover, showed same trend. Some changes in the peaks of $\alpha$ and $\beta$ pinene in the chromatograms could be due to the breakdown of occurring components on relative percentage.

Similarly, (Khorasaninejad et al., 2011) on peppermint (Mentha piperita L.) noticed that the highest content of mentone and menthofuran were obtained under $100 \%$ field capacity, while the highest values of menthol were obtained under the water stress of $70 \%$ field capacity. Beside (Radacsi et al., 2010) noticed a significant decrease in the proportion of linalool content in the essential oil in Ocimum basilicum plant. 
Likewise (Eiasu et al., 2008) argued that citronellol and citronellyl formate in geranium increase with an increase in the stress level, but the reverse was true for other major essential oil components geraniol and geranyl formate were unaffected by water stress.

\section{Mineral content of the dry herb:}

\subsection{Nitrogen content:}

The data in Table (7) show that in most cuts of the two growing seasons the total nitrogen percentages in the dried herb slightly increased with the increasing water regime. In general, the treatment of irrigation at 24 L/P/W gave relatively the highest total nitrogen percentages in the dried herb in the two cuttings during the two growing seasons. Otherwise, the irrigation treatment 4 L/P/W generally resulted in lower nitrogen percentage in the herb than the treatment of nitrogen 8 and 12 L/P/W in the two cuttings in the two growing season respectively.

This decrease tendency in the total nitrogen percentages in the dried herb of
Cymbopogon citratus plants as a result of reducing water amount could be explained through the increment in the produced dry matter yield, which may lead to a dilution in nitrogen percentages in the dried herb. The decrease in Nitrogen percent a result of water stress may be due to the mobilization of nitrogen ions to the leaves of the plant for the synthesis of special proteins and amino acids as a mechanism to withstand the effect of water stress (Khalil and Yousef 2014), water application improves the growth parameters.

Under water stress, lemon grass removed large quantities of nutrients particularly nitrogen and potassium (Panwar et al., 2011), These results could be supported by the findings of ( El- Attar and Ashour, 2016) on chamomile plants who mentioned that, concentrations of $\mathrm{N}$ $\%$ were generally were affected by the different levels of irrigation intervals. In both seasons, the nitrogen was reduced steadily with increasing irrigation intervals.

Table (7): Effect of water regime on $N, P$ and $K$ percentage in the dried leaves of lemongrass plant.

\begin{tabular}{|c|c|c|c|c|c|c|c|c|c|c|c|c|}
\hline \multirow{3}{*}{$\begin{array}{c}\text { Treatment of } \\
\text { Water regime } \\
\text { liters/plant/week }\end{array}$} & \multicolumn{4}{|c|}{ N \% } & \multicolumn{4}{|c|}{ P \% } & \multicolumn{4}{|c|}{ k \% } \\
\hline & \multicolumn{2}{|c|}{$1^{\text {st }}$ season } & \multicolumn{2}{|c|}{$2^{\text {nd }}$ season } & \multicolumn{2}{|c|}{$1^{\text {st }}$ season } & \multicolumn{2}{|c|}{$2^{\text {nd }}$ season } & \multicolumn{2}{|c|}{$1^{\text {st }}$ season } & \multicolumn{2}{|c|}{$2^{\text {nd }}$ season } \\
\hline & $\begin{array}{l}1^{\text {st }} \\
\text { cut }\end{array}$ & $\begin{array}{l}2^{\text {nd }} \\
\text { cut }\end{array}$ & $\begin{array}{l}1^{\text {st }} \\
\text { cut }\end{array}$ & $\begin{array}{l}2^{\text {nd }} \\
\text { cut }\end{array}$ & $\begin{array}{l}1^{\text {st }} \\
\text { cut }\end{array}$ & $\begin{array}{l}2^{\text {nd }} \\
\text { cut }\end{array}$ & $\begin{array}{l}1^{\text {st }} \\
\text { cut }\end{array}$ & $\begin{array}{l}2^{\text {nd }} \\
\text { cut }\end{array}$ & $\begin{array}{l}1^{\text {st }} \\
\text { cut }\end{array}$ & $\begin{array}{l}2^{\text {nd }} \\
\text { cut }\end{array}$ & $\begin{array}{l}1^{\text {st }} \\
\text { cut }\end{array}$ & $\begin{array}{l}2^{\text {nd }} \\
\text { cut }\end{array}$ \\
\hline 24 & 1.33 & 1.18 & 1.18 & 1.03 & 0.213 & 0.168 & 0.21 & 0.17 & 3.57 & 3.92 & 3.59 & 3.88 \\
\hline 12 & 1.30 & 1.17 & 1.17 & 1.21 & 0.197 & 0.162 & 0.2 & 0.163 & 3.49 & 3.62 & 3.38 & 3.68 \\
\hline 8 & 1.26 & 1.15 & 1.17 & 1.16 & 0.182 & 0.150 & 0.19 & 0.158 & 3.53 & 3.61 & 3.55 & 3.65 \\
\hline 4 & 1.25 & 1.03 & 1.15 & 1.11 & 0.147 & 0.152 & 0.15 & 0.157 & 3.48 & 3.54 & 3.51 & 3.66 \\
\hline Mean & 1.29 & 1.13 & 1.17 & 1.13 & 0.18 & 0.16 & 0.19 & 0.16 & 3.52 & 3.67 & 3.51 & 3.72 \\
\hline
\end{tabular}


In general, moisture stress induces an increase in $\mathrm{N}$ (Wu and Garg 2003). These results similar with (Chakrabotry et al. 2010) showed that the $N$ uptake of lemongrass was positively influenced by different irrigation regimes.

\subsection{Phosphorus content:}

The data in Table (7) show that, the water regime had no clear effect on the total phosphorus percentage in the dried herb of lemongrass plants in the two cuttings during the two growing seasons. The reduction in phosphorus $\%$ might be due to the reduction of root activity and leaf water potential (Wu and Garg 2003), due to water stress which restricted the plant's ability to absorb $P$ through its root (Khalil and Yousef, 2014).

\subsection{Potassium content:}

The data in the Table (7) show that, potassium percentage in the leaves of the dried lemongrass herb were increased with increasing water regime in the two cuttings in the growing seasons of 2015 and 2016 respectively. The treatment of irrigated at 24 L/P/W resulted in relatively higher $\mathrm{K} \%$ in the dried herb compared to treatments of watering at 12 , 8 and 4 liters/plant/week. Whereas, the obtained herb from the irrigated plants at 4 L/P/W was contained generally the lowest K-percentages compared to the other water regime during the two experimental seasons. For example, $\mathrm{K} \%$ was between (3.92\%) and (3.54 \%) in the second cutting of the first season for the treatments of watering at 24 and 4 L/P/W respectively. These decrease in potassium $\%$ as water quantity decrease might be as a result of the mobilization of $K$ ions from the leaves to the roots in response to water stress to increase the osmotic potential of the sap of the roots to help the plants to withstand the effects of water stress (Khalil and Yousef, 2014).
Opposite to that (Bahreininejad et al. 2013) on Thymus daenensis demonstrated that the plant under moderate water stress had no effect on $\mathrm{K}+$ content, but severe water stress increased $\mathrm{K}+$ content. Due to in plants coping with water stress, the accumulation of $\mathrm{K}+$ may be more important than the production of organic solutes during the initial adjustment phase, also (El- Attar and Ashour 2016) on chamomile assured that.

\section{REFERENCES}

Abdel-kader, H.H., Seham M. A. ElGamal, A. M. Hamza, Hekmat, Y. Massoud and Fatma K. Youssef (2014). Effect of irrigation intervals and foliar fertilization on lemongrass (Cymbopogon citratus (DC.)Stapf) Plant.journal Plant Production, Mansoura Univ., 5 (9): 1505-1522.

Abdou, M. H., A. A. El-Sayed, R. A. Taha and M. K. El-Nady (2014). Effect of compost and NPK with biofertilizers on growth and essential oil production of lemongrass (Cymbopogon citratus). Scientific Journal of Flowers and Ornamental Plants, 1(3): 243-252.

Alagumalai, A. (2015). Combustion characteristics of lemongrass (Cymbopogon flexuosus) oil in a partial premixed charge compression ignition engine. Alexandria Engineering Journal, 54(3): 405-413.

Bahreininejad, B., J. Razmjoo and $M$. Mirza (2013). Influence of water stress on morpho-physiological and phytochemical traits in Thymus daenensis. International Journal of Plant Production, 7(1): 151-166.

Bayala, B., I. H. N. Bassole, C. Gnoula, R. Nebie, A. Yonli, L. Morel and J. Simpore (2014). Chemical composition, antioxidant, antiinflammatory and anti-proliferative activities of essential oils of plants 
from Burkina Faso. PLOS One, 9(3): 92-122.

Bayala, B., I. H. Bassole, S. Maqdasy, S. Baron, J. Simpore and J. M. A. Lobaccaro (2018). Cymbopogon citratus and Cymbopogon giganteus essential oils have cytotoxic effects on tumor cell cultures. Identification of citral as a new putative antiproliferative molecule. Biochimie.

Ben-Zioni, A., C. Itai and Y. Vaadia (1967). Water and salt stresses, kinetin and protein synthesis in tobacco leaves. Plant Physiology, 42(3), 361-365.

Binu, K. S., S. Prabhakar, S. A. A. Ashf and C. V. Jagdeesh (2013). Performance test for lemon grass oil in single cylinder diesel engines source. J. Eng. Appl. Sci, (8): 455-458.

\section{British pharmacopoeia}

(1963).

Determination of volatile oil in drugs. The pharmaceutical Press, London.

Brunner, P. H. (1978). Methods of analysis of sewage sludge solid wastes and compost. In Methods of analysis of sewage sludge solid wastes and compost. IRC.

CAPMAS (2017). Central agency for public mobilization and statistics of Egypt, from http:II www.capmas.gov.eg.

Chakraborty, H., R. R. Sethi, P. S. Brahmanand, K. G. Mandal, R. B. Singandhupe, A. Kumar (2010). Effect of irrigation regimes and nitrogen levels on herbage and oil yield, oil quality, nutrient uptake and economics of lemongrass (Cymbopogon flexuosus) in a sandy loam soil of Orissa.Indian Journal of Agricultural Sciences, 80(8): 713.

Chen, L. N. (2018). Communicating health and wellness: The meaning behind names of handmade soaps. English Today, 1-6.

Cottenie, A., M. Verloo, M. Velghe and R. Camerlynck (1982). Chemical Analysis of Plant and Soil.Laboratory of Analytical and Agro chemistry. State Univ. Ghent, Belgium.

Eiasu, BK, P. Soundy and JM Steyn (2008). High irrigation frequency and brief water stress before harvest enhances essential oil yield of rosescented gera- nium (Pelargonium capitatum). Hort Science 43: 500-504

Eiasu, B. K. (2009). Influence of soil water management on plant growth, essential oil yield and oil composition of rose-scented geranium (Pelargonium spp.) (Doctoral dissertation).

Eissa, M. A., S. A. Rekaby, S. A. Hegab and H. M. Ragheb (2018). Effect of deficit irrigation on drip-irrigated wheat grown in semi-arid conditions of Upper Egypt. Journal of Plant Nutrition, 1-11.

Elansary, H. O., K. Yessoufou, S. Shokralla, E. A. Mahmoud and K. Skalicka-Woźniak (2016). Enhancing mint and basil oil composition and antibacterial activity using seaweed extracts. Industrial Crops and Products, 92: 50-56.

EL-Attar, A. B. and H. A. Ashour (2016). "The influences of Bio-stimulator Compounds on growth, essential oil and chemical composition of chamomile plants grown under water stress", Arabian Journal of Medicinal \& Aromatic Plants, 2(1): 1-27.

El-Mekawy, M. A. M. (2013). Response of Achillea santolina $L$. to fertilizers under different Irrigation intervals. Asian J. Crop Sci, 5: 338-359.

Farooq, M., A. Wahid, N. Kobayashi, D. Fujita and S. M. A. Basra (2009). Plant drought stress: effects, mechanisms and management. In Sustainable agriculture (pp. 153-188). Springer Netherlands.

Ferreira, D. D. F., F. M. D. Nora, B. N. Lucas, C. R. D. Menezes, A. J. 
Cichoski, S. R. Giacomelli and J. S. Barin (2017). Oxygen introduction during extraction and the improvement of antioxidant activity of essential oils of basil, lemon and lemongrass. Ciência Rural, 47(8).

Gerami, F., P. R. Moghaddam, R. Ghorbani and A. Hassani (2016). Effects of irrigation intervals and organic manure on morphological traits, essential oil content and yield of oregano (Origanum vulgare L.). Anais da Academia Brasileira de Ciências, 88(4): 2375-2385.

Ghassemi-Golezani, K., B. Andalibi, S. Zehtab-Salmasi and J. Saba (2008). Effects of water stress during vegetative and reproductive stages on seed yield and essential oil content of dill (Anethum graveolens L.). Journal of Food Agriculture. Environ, 6(3-4): 282-284.

Hamed, E. S., W. I. M. Toaima and M. ElShazly (2017). Effect of planting density and biofertilization on growth and productivity of Cymbopogon citratus (DC.)Stapf.(Lemongrass) plant under Siwa Oasis conditions. Journal of Medicinal Plants, 5(2): 195-203.

Hani, M. M., S. A. A. H. Hussein, M. H. Mursy, W. Ngezimana and F. N. Mudau (2015). Yield and essential oil response in coriander to water stress and phosphorus fertilizer application. Journal of Essential Oil Bearing Plants, 18(1): 82-92.

Hendawy, S. F., M. S. Hussein, A. E. A. Youssef and R. A. El-Mergawi (2013). Response of Silybum marianum plant to irrigation intervals combined with fertilization. Bioscienc, 5(1): 22-29.

Khalil, N. A. A., Y. M. Dagash and S. O. Yagoub (2013). Effect of sowing date, irrigation intervals and fertilizers on safflower (Carthamus tinctorius L.) yield. Discourse Journal of Agriculture and Food Sciences, 1(5): 97-102.
Khalil, S. E. and R. M. Yousef (2014). Study the effect of irrigation water regime and fertilizers on growth, yield and some fruit quality of Hibiscus sabdariffa L. Int Journal of Adv Res, 2(5): 738-750.

Khorasaninejad, S., A. Mousavi, H. Soltanloo, K. Hemmati and A. Khalighi (2011). The effect of drought stress on growth parameters, essential oil yield and constituent of Peppermint (Mentha piperita L.). Journal of Medicinal Plants Research, 5(22), 5360-5365.

Koyro, H. W. and B. Huchzermeyer (2018). Coordinated Regulation of Photosynthesis in Plants Increases Yield and Resistance to Different Types of Environmental Stress. In Plant Metabolites and Regulation Under Environmental Stress (pp. 281309).

Lovisolo, C. and A. Schubert (1998). Effects of water stress on vessel size and xylem hydraulic conductivity in Vitisvinifera L. Journal of experimental botany, 49(321): 693-700.

Mao, G. F., X. C. Mo, H. Fouad, G. Abbas and J. C. Mo (2018). Attraction behaviour of Anagrusnilaparvatae to remote lemongrass (Cymbopogon distans) oil and its volatile compounds. Natural product research, 32(5): 514-520.

Maruoka, T., A. Kitanaka, Y. Kubota, G. Yamaoka, T. Kameda, O. Imataki and T. Tanaka (2018). Lemongrass essential oil and citral inhibit Src/Stat3 activity and suppress the proliferation/survival of small-cell lung cancer cells, alone or in combination with chemotherapeutic agents. International journal of oncology, 52(5): 1738-1748.

Molle, F., I. Gaafar, D. E. El-Agha and E. Rap (2018). The Nile delta's water and salt balances and implications for 
management. Agricultural Water Management, 197: 110-121.

Moradi, P. (2014). Use of metabolomics to study water deficit stress on the medicinal plant thyme (Doctoral dissertation, University of Birmingham).

Nakamura, Y., M. Miyamoto, A. Murakami, H. Ohigashi, T. Osawa and K. Uchida (2003). A phase II detoxification enzyme inducer from lemongrass: identification of citral and involvement of electrophilic reaction in the enzyme induction. Biochemical and Biophysical Research Communications, 302(3): 593-600.

Panwar, R., S. Dwivedi and S. Rao (2011). Effect of soil (ring method) and leaf (foliar method) applied urea on growth and yield traits in Lemon Grass (Cymbopogon flexuosus) variety RRL 16 in different seasons. The journal of rural and agricultural research, 1 (2): 36-38.

Rahmani, N., J. Daneshian, H. A. Farahani and T. Taherkhani (2011). Evaluation of nitrogenous fertilizer influence on oil variations of Calendula (Calendula officinalis L.) under drought stress conditions. Journal of Medicinal Plants Research, 5(5): 696-701.

Radácsi, P., K. Inotai, S. Sárosi, P. Czövek, J. Bernáth and É. Németh (2010). Effect of water supply on the physiological characteristic and production of basil (Ocimum basilicum L.). European Journal of Horticultural Science, 75(5): 193.

Rehman, R., M. A. Hanif, Z. Mushtaq, B. Mochona and $X$. Qi (2016). Biosynthetic Factories of Essential Oils: The Aromatic Plants. Natural Products Chemistry \& Research.

Schuppler, U., P. H. He, P. C. John and R. Munns (1998). Effect of water stress on cell division and Cdc2-like cell cycle kinase activity in wheat leaves. Plant physiology, 117(2): 667-678.

Shaalan, M., M. El-Mahdy, M. Saleh and M. El-Matbouli (2018). Aquaculture in Egypt: Insights on the Current Trends and Future Perspectives for Sustainable Development. Reviews in Fisheries Science \& Aquaculture, 26(1): 99-110.

Singh, M. and S. Ramesh (2002). Agronomic Investigation On Sweet Basil. Plant Resources Utilization, 197.

Singh, R., S. Singh, B. Sharma, J. Kumar, M. Soni and P. Agrahari (2016). Effect of irrigation and nitrogen on plant growth and stalk yield of lemongrass (Cymbopogon flexuosos S.).

Somparn, N., S. Saenthaweeuk, J. Naowaboot, A. Thaeomor and V. Kukongviriyapan (2018). Effect of lemongrass water extract supplementation on atherogenic index and antioxidant status in rats. Acta Pharmaceutica, 68(2): 185-197.

Taiz, L. and E. Zeiger (2006). Plant physiology. 4th. Sinauer Associate, Sunderland, Mass.,764 PP, EUA.

Tatrai, Z. A., R. Sanoubar, Z. Pluhár, S. Mancarella, F. Orsini and G. Gianquinto (2016). Morphological and Physiological Plant Responses to Drought Stress in Thymus citriodorus. International Journal of Agronomy, 2016, 1-8.

Van Oosten, M. J., O. Pepe, S. De Pascale, S. Silletti and A. Maggio (2018). The role of biostimulants and bioeffectors as alleviators of abiotic stress in crop plants. Chemical and Biological Technologies in Agriculture, 4(1): 5.

Venugopal, C. K. (2010). Stability analysis of Lemongrass genotypes (Doctoral dissertation, UAS, Dharwad).

Venzon, L., L. N. B. Mariano, L. B. Somensi, T. Boeing, P. de Souza, T. M. Wagner and L. M. daSilva (2018). 
Essential oil of Cymbopogon citratus (lemongrass) and geraniol, but not citral, promote gastric healing activity in mice. Biomedicine \& Pharmacotherapy, 98: 118-124.

Webster, R. and R. M. Lark (2018). Analysis of variance in soil research: let the analysis fit the design. European Journal of Soil Science, 69(1): 126-139.

Wu, R. and A. Garg (2003). Engineering rice plants with trehalose-producing genes improves tolerance to drought, salt, and low temperature. ISB news report, 3-7.

Yadav, R. K., R. S. Sangwan, F. Sabir, A. K. Srivastava and N. S. Sangwan (2014). Effect of prolonged water stress on specialized secondary metabolites, peltate glandular trichomes, and pathway gene expression in Artemisia annua L. Plant physiology and biochemistry, 74: 7083.

Zhu, J. K. (2002). Salt and drought stress signal transduction in plants. Annual review of plant biology, 53(1): 247-273. 
دراسة تأثير ندرة ماء الري على النمو والمحصول ومحتوى الزبت الطيار لنبات حشيشة الليمون حقليا.

خالد المرسى مزروع(1) ، إبراهيم عبد المقصود إبراهيم(1) ، السيد عبد الخالق العبساوى(2)،

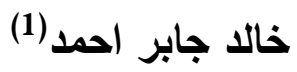

(1) قسم البيوتكنولوجيا النباتية - معهد بحوث الهندسة الوراثية التكنولوجيا الحيوية - جامعة مدينة السادات. (2) قسم المعلوماتية الحيوية - معهة بحوث الهندسة الوراثية التكنولوجيا الحيوية - جامعة مدينة السادات. الملخص العربي أجريت تجربتان حقليتان على نبات حشيثـة الليمون بمزرعة خاصـة بزمسام الخطاطبة -مركز السـادات - محافظة

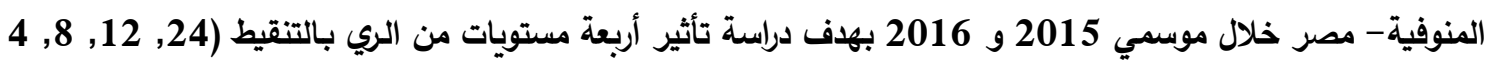
لتر/نبات/أسبوع) على كل من النمو الخضري ونسبة ومحتوى محصول الزيت الطيار ومكوناته وكذلك التركيب الكيماوي

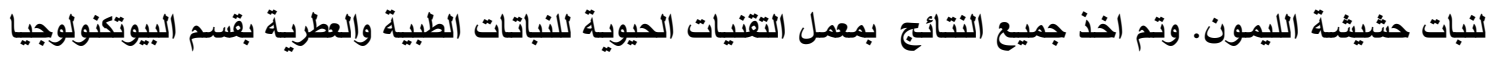

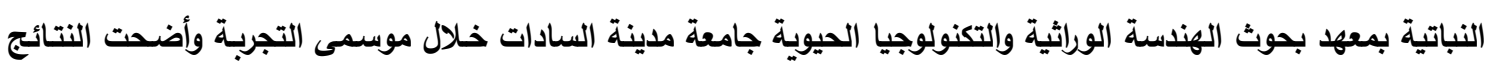

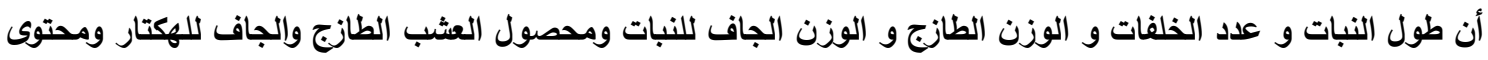

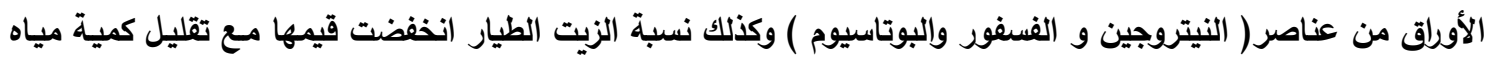

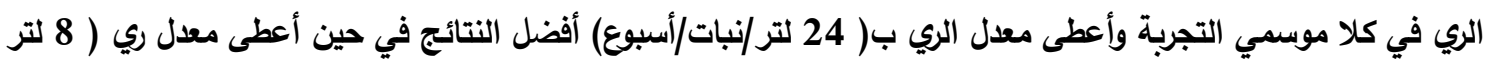
/نبات/ أسبوع) أفضل جودة لمحصول الزيت الطيار (محتواه من السترال الكلى).



